DOI: $10.17951 / \operatorname{lrp} .2019 .38 .4 .181-194$

Katarzyna Skalska

Uniwersytet Marii Curie-Skłodowskiej

ORCID - 0000-0003-2051-5215

\title{
PROJEKT DOBRE ŻYCIE REALIZOWANY NA UNIWERSYTECIE MARII CURIE-SKŁODOWSKIEJ W LUBLINIE JAKO PRZYKŁAD PROJEKTOWANIA UNIWERSALNEGO
}

\begin{abstract}
Streszczenie: Artykuł przedstawia doświadczenia Uniwersytetu Marii Curie-Skłodowskiej z zakresu projektowania uniwersalnego na poziomie edukacji wyższej. Projektowanie uniwersalne w edukacji zakłada tworzenie programów, materiałów, ale również otoczenia dostępnego dla studentów o różnych potrzebach wynikających ze stylu uczenia się, wieku, stanu zdrowia, znajomości języka, doświadczeń życiowych i kulturowych. W projekcie o charakterze profilaktycznym Dobre życie została wykorzystana idea projektowania uniwersalnego. Głównym celem projektu było przeciwdziałanie zachowaniom samobójczym wśród młodzieży akademickiej. Podjęte działania zgodnie z ideą projektowania uniwersalnego zostały skierowane do całej społeczności akademickiej i zostały oparte na modelu działania składającym się z czterech ogniw: student, grupa rówieśnicza, nauczyciele akademiccy, Zespół ds. Osób Niepełnosprawnych.
\end{abstract}

Słowa kluczowe: projektowanie uniwersalne, student, samobójstwo

Przemiany społeczne, związane z rosnącymi wymaganiami rynku pracy oraz ze wzrostem postępu technicznego, powodują wydłużenie procesu edukacji młodych ludzi. Jednym z sukcesów ilościowych polskiej edukacji jest wysoki wskaźnik skolaryzacji, który na poziomie wyższym wynosi 50\% (Banach 2011, s. 13). Wykształcenie wyższe jest źródłem szczęścia dla Polaków - osoby z dyplomem uczelni mają trzykrotnie wyższy wskaźnik poczucia szczęścia niż osoby z wykształceniem zasadniczym, nie uwzględniając takich zmiennych, jak wiek, dochód i status zawodowy (Czapiński 2015, s. 121). 
Taki stosunek do wykształcenia ma pozytywne konsekwencje społeczne, ponieważ edukacja przeciwdziała niekorzystnym zjawiskom społecznym dzięki oddziaływaniu opartym na przekazie wartości, kształtowaniu postaw i rozwijaniu umiejętności (Fajfer-Kruczek 2015, s. 69). Jedną z takich wartości powinien być właściwy stosunek do osób, które ze względu na stan zdrowia mogą doświadczać trudności w różnych obszarach swojego życia. Stosunek ten powinien być zakorzeniony w przekonaniu o równej wartości etycznej życia każdego człowieka, a także poparty umiejętnością tworzenia przyjaznych więzów z ludźmi, którzy są defaworyzowni społecznie (Nowak 2012, s. 187). Takie kształcenie młodzieży akademickiej wpisuje się również w nurt demokratyzacji szkolnictwa wyższego, związanego ze złagodzeniem zasad rekrutacji, a w konsekwencji powodującego otwarcie uczelni na problemy przeciętnych obywateli (Ćwikliński 2014, s. 145).

Jednym z takich problemów według raportu World Health Organization (WHO) (2014, s. 7) jest wzrastająca liczba samobójstw wśród młodych ludzi w wieku 15-29 lat. W niektórych krajach na świecie jest to druga przyczyna zgonów w tej grupie wiekowej. Uczelnie wyższe kształcące masowo młodych ludzi powinny podjąć działania, których celem jest przeciwdziałanie zachowaniom samobójczym wśród młodzieży akademickiej. Samobójstwo jest wydarzeniem tragicznym dla osoby, która go dokonała, ale również dla jej najbliższych i całej społeczności, w której żyła.

Uniwersytet Marii Curie-Skłodowskiej, by odpowiedzieć na współczesne wyzwania, zainicjował w roku akademickim 2017/2018 projekt Dobre życie, którego głównym celem było przeciwdziałanie zachowaniom samobójczym wśród młodzieży akademickiej. W opracowaniu projektu zostały wykorzystane wytyczne do prowadzenia działań profilaktycznych w szkołach (Szymańska 2016, Światowa Organizacja Zdrowia, Polskie Towarzystwo Suicydologiczne 2003, Światowa Organizacja Zdrowia, Rzecznik Praw Dziecka, Ministerstwo Edukacji Narodowej, Polskie Towarzystwo Suicydologiczne 2007), a także doświadczenia i wnioski wyciągnięte z prowadzonego we wcześniejszych latach akademickich na Uniwersytecie Marii Curie-Skłodowskiej projektu Przyjazny Uniwersytet, którego głównym celem było wdrożenie programu wsparcia dla studentów doświadczających kryzysów zdrowia psychicznego. W ciągu kilku lat realizacji projektu działania o charakterze wspierającym ewoluowały w kierunku promocji zdrowia psychicznego w środowisku akademickim, a także projektowania uniwersalnego (Skalska 2018, s. 156).

Idea projektowania uniwersalnego powstała w latach 70. XX wieku, jej twórcą był architekt Ronald Mace (za: Ślusarczyk 2013, s. 67), który zdefiniował projektowanie uniwersalne jako tworzenie produktów i otoczenia dostępnego dla wszystkich ludzi, bez potrzeby stosowania dodatkowych adaptacji. Początkowo idea ta odnosiła do architektury, lecz z czasem znalazła zastosowanie we wzornictwie przemysłowym, Frank Bowe zaś opisał jej zastosowanie w edukacji. 
Koncepcja projektowania uniwersalnego w edukacji zakłada, że programy, materiały, ale również otoczenie, są dostosowane do studentów o różnych potrzebach wynikających ze stylu uczenia się, wieku, stanu zdrowia, znajomości języka, doświadczeń życiowych i kulturowych (Funckes 2010, s. 9). Projektowanie uniwersalne jest również narzędziem do kształtowania świadomości społecznej poprzez projektowanie środowiska społecznego, zapewniającego całej społeczności pełne uczestnictwo we wszystkich obszarach funkcjonowania na równych zasadach (Adaszyńska 2017, s. 18).

Szansą na zapewnienie pełnego uczestnictwa w społeczności akademickiej dla studentów doświadczających kryzysu zdrowia psychicznego są działania rozwijające kompetencje, mające wpływ na zdrowie psychiczne, które jest kształtowane obok czynników biologicznych i psychologicznych również przez interakcje społeczne i środowiskowe (Czabała 2015, s. 17). Dlatego w projekcie Dobre życie, by zrealizować główny cel związany z przeciwdziałaniem zachowaniom samobójczym wśród młodzieży akademickiej, zostały zaplanowane następujące cele szczegółowe:

1) zwiększenie świadomości środowiska akademickiego w zakresie potrzeb zdrowia psychicznego;

2) przeciwdziałanie niekorzystnym zjawiskom społecznym, takim jak: samotność, trudności w komunikacji, wykluczenie studentów doświadczających kryzysów zdrowia psychicznego, wypalenie zawodowe u nauczycieli akademickich;

3) podnoszenie jakości życia społeczności akademickiej poprzez promowanie znaczenia tworzenia pozytywnych relacji w środowisku akademickim, również o charakterze towarzyskim.

By prawidłowo zaplanować działania profilaktyczne, odpowiadając na potrzeby wszystkich członków społeczności akademickiej, w projekcie Dobre życie zostały uwzględnione trzy poziomy profilaktyki:

- profilaktyka uniwersalna - adresowana jest do całej społeczności, a jej głównym zadaniem obok zapobiegania zachowaniom ryzykownym jest dostarczanie wiedzy i rozwijanie umiejętności psychologicznych i społecznych, które są istotne dla zapobiegania problemom;

- profilaktyka selektywna - kierowana jest do grup zwiększonego ryzyka, a jej celem jest opóźnienie inicjacji w zakresie zachowań ryzykownych; w działaniach uwzględniona jest specyfika potrzeb i problemów tej grupy;

- profilaktyka wskazująca - kierowana jest bezpośrednio do jednostek z grup zwiększonego ryzyka, u których mogą występować wczesne symptomy dysfunkcji i sygnały o ważnych problemach; główne działania skoncentrowane są na diagnozie przyczyn i interwencji, działania te nie mają charakteru terapeutycznego (B. Jankowska, A. Matysiak-Błaszczak 2017, s. 301). 
Biorąc pod uwagę powyższe wytyczne, związane zarówno z prawidłowo przeprowadzonymi oddziaływaniami profilaktycznymi, jak i z projektowaniem uniwersalnym, działania w projekcie Dobre życie zostały zaplanowane zgodnie z poniższym modelem. Model działań uwzględnia specyfikę środowiska akademickiego, a także pozwala na prowadzenie oddziaływań profilaktycznych, które uwzględniają relacje pomiędzy poszczególnymi elementami modelu.

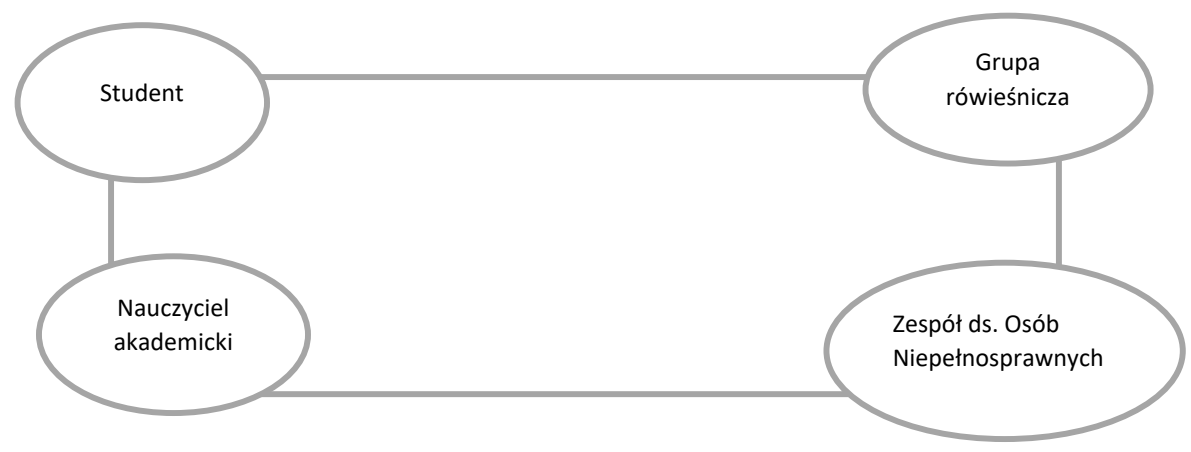

Rysunek 1. Model działań w projekcie Dobre życie na Uniwersytecie Marii

Curie-Skłodowskiej

\section{STUDENT}

Program profilaktyczny, który zgodny z zasadami projektowania uniwersalnego ma odpowiedzieć na potrzeby wszystkich studentów, powinien więc uwzględniać potrzeby wynikające zarówno z okresu wczesnej dorosłości, jak i specyfikę funkcjonowania w kryzysie zdrowia psychicznego.

O rozwoju studentów, którzy znajdują się w okresie wczesnej dorosłości, stanowi przygotowanie do podejmowania zadań rozwojowych, ponieważ ich realizacja wymaga zdobycia nowych kompetencji, a tym samym wiąże się ze zmianą $\mathrm{w}$ dotychczasowym sposobie funkcjonowania jednostki. Zadania $\mathrm{w}$ tym okresie ogniskują się wokół następujących obszarów aktywności: rodzinnej (wybór współmałżonka, uczenie się współżycia z nim, założenie rodziny, wychowanie dzieci, prowadzenie domu); zawodowej (rozpoczęcie pracy zawodowej, podjęcie obowiązków zawodowych), towarzyskiej (znalezienie pokrewnej grupy społecznej); obywatelskiej (podjęcie odpowiedzialności obywatelskiej) (Harwas-Napierała 2012, s. 57). Rozwój w okresie wczesnej dorosłości jest tak samo ważny, jak w okresach wcześniejszych, jednak jego wyjątkowość polega na większej 
samoświadomości, która wynika z rozwoju osobowości, i wyższym poziomie rozwoju społecznego. Ponadto w tym okresie następuje nasilone poszukiwanie sensu życia, w stosunku do późniejszych okresów rozwojowych (Batory 2013, s. 182).

Jednak okres studiów ze względu na przełom pomiędzy okresem dojrzewania wczesnej dorosłości jest uznawany w psychiatrii za okres podwyższonego ryzyka wystąpienia kryzysów psychicznych. Przyczynami tych trudności mogą być dodatkowo następujące zmiany: otoczenia, większa odpowiedzialność finansowa, nowy system kształcenia, a także relacje uczuciowe (Nowak-Adamczyk 2014, s. 76). Osoby przeżywające kryzysy zdrowia psychicznego narażone są w procesie studiowania na przeżywanie negatywnych emocji w postaci stresu i lęku, które wiążą się z koniecznością spełniania konkretnych wymagań, a także ekspozycją społeczną. Trudności w sferze edukacyjnej mogą rzutować na relacje interpersonalne, w których student może przeżywać obawy, utrudniające rozwijanie kompetencji społecznych, niezbędnych do realizacji zadań rozwojowych wczesnej dorosłości (Podgórska-Jachnik, Pietras 2014, s. 156).

Z badań Rzecznika Praw Obywatelskich nad dostępnością edukacji akademickiej dla osób z niepełnosprawnością (RPO 2015, s. 42) wynika, że ta grupa studentów pozostaje w cieniu, nie ujawniając potrzeb płynących ze stanu zdrowia $\mathrm{z}$ obawy negatywnej reakcji otoczenia i stygmatyzacji. W sytuacji trudności akademickich starają się swoje sprawy załatwiać osobiście lub przez bliskie osoby. W konsekwencji braku odpowiedniego wsparcia rezygnują ze studiów.

Grupa, do której szczególnie skierowany był projekt, to studenci z grupy ryzyka zachowań suicydalnych. Na podstawie badań przeprowadzonych przez WHO 90\% aktów samobójczych dokonują osoby, które są w nastroju lub stanie depresyjnym. Depresja może być wywołana przez środki psychoaktywne, chorobę afektywną, traumatyczne wydarzenia, przewlekły stres (Szymańska 2016, s. 14).

Zachowania samobójcze, które nie wynikają z choroby psychicznej, powstają w wyniku interakcji czynników indywidualnych, rodzinnych i środowiskowych. Czynniki, które mogą chronić młodzież przed zachowaniami suicydalnymi, są następujące:

- dobre relacje rodzinne i wsparcie ze strony rodziny;

- prawidłowy styl poznawczy i cechy osobowości - umiejętności społeczne, wiara w siebie, umiejętność poszukiwania pomocy, na początkowym etapie trudności, umiejętność skorzystania z porady innych, przy dokonywaniu ważnych dla siebie wyborów, otwartość na innych ludzi i różne od własnego sposoby rozwiązywania problemów, otwartość na nową wiedzę;

- czynniki kulturowe i socjodemograficzne - integracja społeczna, dobre relacje $\mathrm{w}$ grupie rówieśniczej, dobre relacje z nauczycielami, wsparcie ze 
strony innych osób (Światowa Organizacja Zdrowia, Polskie Towarzystwo Suicydologiczne 2003, s. 14).

$\mathrm{Na}$ brak powyższych czynników ochronnych wskazują również osoby, które zostały uratowane po próbie samobójczej, wymieniając następujące motywy:

- $28 \%$ badanych wskazuje na problemy egzystencjalne, do których zaliczają brak sensu życia, zagubienie w świecie, osamotnienie, nieumiejętność nawiązania kontaktu $\mathrm{z}$ rówieśnikami;

- $24 \%$ badanych wskazuje na konflikty w życiu rodzinnym - niezrozumienie przez rodziców, poczucie odrzucenia przez rodziców, konflikty rodziców $\mathrm{z}$ rodzeństwem;

- pozostali badani wskazywali na konflikty z sympatią, współmałżonkiem, trudności w nauce w szkole i na uczelni.

Dodatkowy czynnik, który występuje u badanych, to niskie poczucie własnej wartości i przypisywanie sobie wyłącznie cech negatywnych (Hołyst 2012, s. 566).

Ulf Otto (za: Hołyst 2012, s. 569) sprowadza motywy samobójstw do czterech podstawowych: cierpienia, depresji, samotności i nieefektywnej komunikacji. Elżbieta Jundziłł $(2005$, s. 77$)$ dodaje do przyczyn samobójstw: lęk przed życiem i podejmowaniem decyzji, a także poczucie bezradności.

Publikacje naukowe i badania empiryczne wskazują, że realizacja zamiaru samobójczego jest długotrwałym procesem i nie należy go oceniać z perspektywy zdarzenia (Marzec-Holka 2005, s. 320). Proces ten ma początek w przedłużającym się kryzysie, by następnie ewoluować w kierunku myśli i tendencji samobójczych, a swoje zakończenie znajduje w decyzji samobójczej. Właściwie udzielona pomoc na początku kryzysu może zapobiec pojawieniu się tendencji samobójczych, które również mogą być zablokowane, jeśli we właściwym czasie zostaną odczytane znaki i sygnały płynące od osoby przeżywającej takie trudności. Pomocy mogą udzielić rodzina, nauczyciele, przyjaciele, osoby bliskie, inni specjaliści mający kontakt ze studentem (Cekiera 2009, s. 9).

Należy podkreślić, że oddziaływania skierowane do studentów, obejmujące działania wzmacniające $\mathrm{w}$ procesie studiowania, mają pozytywny wpływ na wszystkich studentów. Uczenie pozytywnego stosunku do samego siebie, podkreślanie wartości jednostki, a także jej przynależności kulturowej, ma pozytywny wpływ na przebieg procesu uczenia się. Pozytywne wyniki takich oddziaływań można zaobserwować już na wynikach testu, średniej ocen w ciągu miesiąca studiów, a nawet na ogólnym poziomie akademickim i zdrowotnym (Meyer i in. 2016, s. 105).

Ze względu na powyższe informacje, do studentów zostały skierowane następujące działania:

1) akcja informacyjna o wsparciu dostępnym na uczelni, w ramach której wszyscy studenci pierwszego roku otrzymali ulotki informacyjne; 
2) promocja broszury Zaprzyjaźnij się ze soba na studiach, której celem jest dostarczenie informacji z zakresu stresu, porad z efektywnego uczenia się, a także wskazówek dotyczących postępowania;

3) szkolenia dla studentów, które dotyczyły realizacji zadań z okresu wczesnej dorosłości: Bliżej siebie, przyjaciót i partnera; szkolenie było prowadzone cyklicznie, by studenci mogli z niego skorzystać w trakcie całego roku akademickiego;

4) warsztaty $z$ arteterapii, których celem było rozwijanie zainteresowań studentów, a także tworzenie przyjaznej atmosfery, w której mogą podzielić się swoimi emocjami i przemyśleniami; warsztaty prowadziło dwóch specjalistów: psycholog i artysta plastyk;

5) grupa terapeutyczna, której cel był zgodny z nazwą grupy i uczestniczyli w niej studenci, którzy chcieli poprawić swoje funkcjonowanie emocjonalne i społeczne, a także doświadczający kryzysu zdrowia psychicznego.

Zaproponowane działania przede wszystkim podejmowały problematykę przyczyniającą się do wzmacniania w studentach orientacji przyszłościowej, a także pomocną w przygotowaniu do podejmowania zadań rozwojowych okresu wczesnej dorosłości. Działania miały charakter zarówno informacyjny, szkoleniowy, jak i terapeutyczny.

Badania nad młodymi osobami, które podjęły próbę samobójczą, wykazują, że nie potrafią one sprecyzować ról, jakie chcą pełnić w dorosłym życiu, ani stworzyć precyzyjnego obrazu, w którym jest miejsce zarówno na role partnerskie, rodzicielskie, jak i zawodowe (Jundziłł 2005, s. 83). Należy podkreślić, że oddziaływania skierowane do studentów, obejmujące działania wzmacniające w procesie studiowania, mają pozytywny wpływ na wszystkich studentów. Uczenie pozytywnego stosunku do samego siebie, podkreślanie wartości jednostki, a także jej przynależności kulturowej, ma pozytywny wpływ na przebieg procesu uczenia się. Pozytywne wyniki takich oddziaływań można zaobserwować już na wynikach testu, średniej ocen w ciągu miesiąca studiów, a nawet na ogólnym poziomie akademickim i zdrowotnym (Meyer i in. 2016, s. 105).

Kolejne działania w ramach projektu zostały skierowane do studentów, jako potencjalnej grupy wsparcia w sytuacji kryzysowej.

\section{GRUPA RÓWIEŚNICZA}

Radzenie sobie młodzieży z trudnymi sytuacji zależy nie tylko od specyfiki trudnej sytuacji i uwarunkowań podmiotowych, ale również od relacji z innymi ludźmi, a szczególnie z rodziną i rówieśnikami. Przeciwieństwem takich relacji jest samot- 
ność, która jest przeżywana jako bolesny stan psychiczny. Z niej może się zrodzić poczucie braku więzi z drugim człowiekiem, zaburzenie wewnętrznej harmonii, poczucie braku kontaktu z innymi ludźmi, a nawet z samym sobą (Papież 2005, s. 92). Dlatego tak duże znaczenie w życiu młodego człowieka obok rodziny ma grupa rówieśnicza - znaczenie to zwiększa się w okresie nastoletnim.

Grupa rówieśnicza wyróżnia się nie tylko ze względu na cechę demograficzną, jaką jest wiek, ale przede wszystkim ze względu na bliskie, nacechowane wzajemną aprobatą uczestnictwo w grupie (Pilch 1995, s. 175). Odgrywa ona istotną rolę w rozwijaniu samodzielności i niezależności, ponieważ w niej młodzi ludzie dzielą się swoimi przemyśleniami, podejmują wspólne cele i gromadzą różne doświadczenia (Liberska 1997, s. 230). W okresie studiów relacje rówieśnicze mogą podnieść poczucie własnego Ja, a także pomóc doświadczyć własnej podmiotowości. W niej studenci weryfikują swoje kompetencje poprzez wzajemne relacje i współdziałanie oraz rozwijają swoje zainteresowania i uzdolnienia (Saran 2014, s. 180).

Szczególnym miejscem w zakresie nabywania nowych doświadczeń społecznych i eksperymentowania z różnymi rolami społecznymi są na uczelniach wyższych koła naukowe. Działalność w kołach naukowych jest również ważnym miejscem do nabywania kompetencji istotnych na rynku pracy: planowania, projektowania, negocjowania, kreatywnego podejścia do problemów, pracy w grupie, a także ewaluacji (Przybylak, Rojek 2011, s. 204).

Uczestniczenie w grupach formalnych i nieformalnych jest dla studentów ważne z punktu widzenia wzbogacenia procesu kształcenia, ale również budowania sytemu wsparcia społecznego. W projekcie Dobre życie do studentów zostały skierowane szkolenia, które miały zwiększyć świadomość studentów w zakresie potrzeb studentów doświadczających kryzysów zdrowia psychicznego. Dlatego do grupy rówieśniczej (studentów zainteresowanych problematyką, a także kół naukowych) zostały skierowane szkolenia, których celem było dostarczenie wiedzy, jak można udzielić wsparcia rówieśnikom, doświadczającym kryzysów. Szkolenia miały charakter świadomościowy, by studenci nie wykluczali swoich rówieśników ze względu na przeżywane przez nich problemy, a także potrafili udzielić adekwatnego do sytuacji wsparcia, szczególnie emocjonalnego.

\section{NAUCZYCIELE AKADEMICCY}

Nauczyciele akademiccy odpowiadają za prawidłowy przebieg procesu dydaktycznego, który w znacznej mierze uzależniony jest, oprócz wiedzy merytorycznej, od kompetencji komunikacyjnych. Pomiędzy studentem a nauczycielem akademickim prowadzony jest ciągły dialog, który odbywa się zarówno w sali wykładowej, jak 
i w czasie konsultacji. To właśnie nauczyciel akademicki powinien we właściwy sposób odczytać intencje studentów oraz płynące od niego komunikaty. Sprawność ta umożliwia dobrą współpracę, konstruktywne rozwiązywanie problemów badawczych, a także wzajemnego wspierania się (Zalewska 2016, s. 22).

Szczególnego znaczenia kompetencje komunikacyjne nauczyciela akademickiego nabierają w kontakcie ze studentem doświadczającym kryzysów zdrowia psychicznego, ponieważ jego stan emocjonalny w znacznym stopniu może wpływać zarówno na proces komunikacji, jak i przyswajania wiedzy. Dlatego do nauczycieli akademickich zostały w ramach projektu Dobre życie skierowane szkolenia dotyczące komunikacji ze studentem w sytuacji kryzysowej, obejmujące następujące zagadnienia: charakterystykę trudności studenta w sytuacji kryzysowej, planowanie procesu dydaktycznego, zasady komunikacji ze studentem w sytuacji kryzysowej. Ważnym aspektem w komunikacji ze studentem jest zachowanie odpowiednich granic wynikających $\mathrm{z}$ roli zawodowej.

Obowiązujące przepisy mogą $\mathrm{w}$ tym zadaniu znacznie pomóc nauczycielom akademickim, ponieważ przebieg procesu studiowania jest szczegółowo określony przez przepisy regulaminu studiów, w którym dokładnie są sprecyzowane prawa i obowiązki studentów. W nim znajdują się również przepisy regulujące wyrównywanie szans edukacyjnych studentów, którzy ze względu na stan zdrowia potrzebują dodatkowych rozwiązań, np. indywidualnej organizacji studiów. Regulamin studiów kreśli ramy, w których powstaje relacja dydaktyczna pomiędzy studentem a nauczycielem akademickim. Należy podkreślić, że w sytuacjach rodzących napięcie emocjonalne, takich jak egzaminy, zaliczenia, rozwiązania regulaminowe mogą pomóc zarówno studentowi, jak i nauczycielowi spojrzeć obiektywnie na sytuację.

Drugim dokumentem istotnym dla projektu Dobre życie jest zarządzenie rektora dotyczące obowiązków opiekuna roku. To właśnie na opiekunie roku spoczywają zadania związane z wdrożeniem studentów w nowe warunki i sytuację: informowanie o zasadach funkcjonowania uczelni, przekazywanie istotnych informacji, zachęcanie studentów do zaangażowania w życie akademickie uczelni poprzez organizowanie spotkań dla studentów z danego roku, ale również zachęcanie do organizacji i uczestnictwa w uroczystościach uniwersyteckich i wydziałowych.

Wymienione obowiązki wykonywane rzetelnie przez nauczycieli akademickich stają się czynnikiem ochronnym, ponieważ pomagają w budowaniu relacji studenta ze społecznością akademicką.

Z rolą zawodową nauczycieli akademickich związane jest także ryzyko wypalenia zawodowego spowodowane wysokim zaangażowaniem w pracę, wzmacnianym przez ciągłe dążenie do perfekcji (Rongińska, Gaida 2012, s. 8). Helena Sęk (2004, s. 149) uzupełnia te przyczyny o ambiwalencję, która wymaga od nauczyciela oscy- 
lowania pomiędzy troską, życzliwością i serdecznością a niezbędnym dystansem pomagającym w dobrym wykonywaniu obowiązku formowania młodych ludzi (Sęk 2004, s. 149).

By przeciwdziałać wypaleniu zawodowemu, a tym samym obniżeniu jakości pracy nauczycieli akademickich, w projekcie Dobre życie zostały zaproponowane szkolenia, które miały wzmocnić kompetencje ww. nauczycieli w zakresie dbania o własny dobrostan, a także budowania wsparcia w grupie zawodowej, które jest istotne dla prawidłowej realizacji zadań zawodowych (Czabała 2015, s. 19).

\section{ZESPÓŁ DS. OSÓB NIEPEŁNOSPRAWNYCH}

W ramach Uniwersytetu Marii Curie-Skłodowskiej działa Zespół ds. Osób Niepełnosprawnych, którego szeroka oferta wsparcia dzięki projektowi Dobre życia mogła zostać wykorzystana w kontekście wsparcia społeczności studenckiej. Dlatego studenci zostali poinformowani o możliwości skorzystania ze wsparcia psychologicznego, będącego profesjonalną pomocą dla osób, które nie radzą sobie z zaspokojeniem swoich potrzeb i realizowaniem zadań rozwojowych, ale potrzebują pomocy w zakresie doskonalenia swoich kompetencji. Głównym zadaniem poradnictwa jest odwołanie się do zasobów w okresach przełomów rozwojowych, osobistych wyzwań czy życiowych kryzysów (Czabała 2015, s. 19).

Jednak system wsparcia na uczelni, który jest skierowany do studentów z niepełnosprawnością, obejmuje formy wsparcia mogące pomóc w efektywnym studiowaniu również studentom doświadczającym kryzysów zdrowia psychicznego.

Formy wsparcia realizowane na Uniwersytecie Marii Curie-Skłodowskiej:

- porady z zakresu efektywnego uczenia się,

- dodatkowe zajęcia sportowe,

- dodatkowe lektoraty z języka angielskiego,

- wyjazdy adaptacyjne i szkoleniowe.

Przedstawione formy wsparcia mają na celu budowanie społeczności dostępnej dla wszystkich studentów poprzez wyrównywanie szans edukacyjnych.

\section{ZAKOŃCZENIE}

Projekt Dobre życie obok przeciwdziałania zachowaniom samobójczym wśród młodzieży akademickiej poszerzał oddziaływanie środowiska edukacyjnego uczelni wyższej o działania wspierające ogólny rozwój człowieka w następujących sferach: emocjonalnej, społecznej, estetycznej. Emocje mają podstawowe znaczenie dla 
procesu uczenia się i nauczania, a wiedza o nich pomaga również w przygotowaniu do pracy w zawodach społecznych, np. zarządzanie zasobami ludzkimi. To właśnie one odgrywają również kluczową rolę w rozwijaniu polityki solidarności i troski o innych. Rozwój wrażliwości jest podstawą empatii i zainteresowania drugim człowiekiem, a szacunek dla własnych potrzeb emocjonalnych uczy współczucia. Właśnie te kompetencje umożliwiają rozwijanie solidarności lokalnej i globalnej (Lynch 2012, s. 53).

By zgodnie $\mathrm{z}$ ideą projektowania uniwersalnego podsumować działania w projekcie, należy stworzyć możliwość podsumowania doświadczeń poprzez dialog i zebranie informacji zwrotnych od członków społeczności akademickiej (Meyer i in. 2016, s. 297). Na podstawie tak przeprowadzonej analizy warto zastanowić się, jakie elementy projektu Dobre życie powinny stać się standardowymi działaniami uczelni wyższych, których zadaniem jest odpowiadanie na wyzwania współczesności.

\section{LITERATURA}

Adaszyńska E., 2017, Projektowanie uniwersalne - dostępność i uczestnictwo dla wszystkich. „Uniwersytet Zielonogórski”, nr 2, 16-18.

Agryle M., 2002, Psychologia stosunków międzyludzkich. Warszawa, Wydawnictwo Naukowe PWN.

Banach C., 2011, Strategia rozwoju edukacji wobec problemów i zadań rozwoju Polski. W: J. Saran, M. Żmigrodzki (red.), Student jako podmiot edukacji we współczesnej uczelni wyższej. Lublin, Wydawnictwo WSEiI, 13-20.

Batory A., 2013, Wspieranie rozwoju między dorastaniem a dorosłościa. W: E. Sokołowska (red.), Psychologia wspierania, rozwoju i kształcenia. Warszawa, Wydawnictwo Akademii Pedagogiki Specjalnej, 167-182.

Cekiera C.M., 2003, Wstęp do wydania polskiego. W: Światowa Organizacja Zdrowia. Polskie Towarzystwo Suicydologiczne. Zapobieganie samobójstwom. Poradnik dla nauczycieli i innych pracowników szkoły. Genewa-Warszawa, Zakład Wydawniczo Produkcyjny Foliał, 7-11.

Ćwikliński A., 2014, Wokół problemów edukacji akademickiej. W: A. Ćwikliński (red.), Edukacja akademicka. Między oczekiwaniami a rzeczywistością. Poznań, Wydawnictwo Naukowe UAM, 141-158.

Czabała J.C., 2015, Poradnictwo psychologiczne. W: C. Czabała, S. Kluczyńska (red.), Poradnictwo psychologiczne. Warszawa, Wydawnictwo Naukowe PWN, 17-44. Czapiński J., 2017, Psychologia szczęścia. Kto, kiedy, dlaczego kocha życie i co z tego wynika, czyli nowa odsłona teorii cebulowej. Warszawa, Wydawnictwo Scholar. 
Fajfer-Kruczek I., 2015, Wykluczenie społeczne osób z niepełnosprawnością $w$ środowisku lokalnym. Katowice, Wydawnictwo Uniwersytetu Śląskiego.

Funckes C., 2010, Projektowanie uniwersalne: zastosowanie w szkolnictwie wyższym.

W: P. Wdówik (red.), Uniwersytet dla wszystkich. Uniwersalne projektowanie zajęć dydaktycznych. Warszawa, Biuro ds. Osób Niepełnosprawnych Uniwersytetu Warszawskiego, 6-17.

Harwas-Napierała B., 2012, Dorosłość jako spełnienie. Drogi i zagrożenia rozwoju człowieka $w$ okresie dorosłości. Kraków, Wydawnictwo Libron.

Hołyst B., 2012, Suicydologia. Warszawa, Wydawnictwo LexisNexis.

Jakimiuk B., 2016, Tworzenie relacji interpersonalnych jako postawa $i$ fundament profesjonalizmu nauczycieli. W: J.M. Łukasik, N.G. Pikuła, K. Jagielska (red.), Rozwój nauczyciela od wczesnej do późnej dorosłości. Kraków, Oficyna Wydawnicza Impuls, 49-64.

Jankowska B., Matysiak-Błaszczyk A., 2017, Profilaktyka skierowana do młodzieży. W: B. Jankowiak, A. Matysiak-Błaszczyk (red.), Młodzież między ochrona a ryzykiem. Wspieranie rozwoju oraz pomoc psychologiczno-pedagogiczna dla adolescentów i adolescentek. Poznań, Wydawnictwo Naukowe UAM, 296-314. Jankowski D., 2006, Środowisko edukacyjne człowieka dorosłego jako problem pedagogiki społecznej i andragogiki. „Rocznik Andragogiczny”, vol. 2006, 47-65. Jankowski D., 2017, Jednostka jako podmiot osobowego rozwoju i kreator swojego środowiska życia. W: A. Knocińska, P. Frąckowiak (red.), Pomoc - wsparcie ratownictwo. O optymalizacji rozwoju i edukacji człowieka na różnych etapach życia. Poznań-Gniezno, 77-82.

Joachimowska M., 2012, Ewaluacja - zaproszenie do rozwoju. Między wyobraźnia a jej brakiem. W: J. Szymanowska (red.), Ewaluacja w pracy socjalnej. Badanie, kształcenie, praktyka. Kraków, Oficyna Wydawnicza Impuls, 49-69.

Jundziłł E., 2005, Problemy samobójcze - odpowiedź młodego pokolenia na trudności $w$ procesie socjalizacji. W: T. Sołtysik (red.), Zagrożenia $w$ wychowaniu i socjalizacji młodziė̇y oraz możliwości ich przezwyciężania. Bydgoszcz, Wydawnictwo Akademii Bydgoskiej im. Kazimierza Wielkiego, 75-86.

Kirke D.M., 2012, Analiza sieci społecznych. W: M. Gray, S.A. Webb, J. Szmaglewski (red.), Praca socjalna. Teorie $i$ metody. Warszawa, Wydawnictwo Naukowe PWN, 179-192.

Liberska H., 1997, W: J. Rostowski, T. Rostowska, I. Janicka (red.), Psychospołeczne aspekty rozwoju człowieka. Łódź, Wydawnictwo Uniwersytetu Łódzkiego, 229-237.

Lynch K., 2012, Oświata jako miejsce zmiany: dbanie o równość i przeciwdziałanie niesprawiedliwości. W: G. Mazurkiewicz (red.), Jakość edukacji. Różnorodne perspektywy. Kraków, Wydawnictwo Uniwersytetu Jagiellońskiego, 29-64. 
Marzec-Holka K., 2005, Determinanty samobójstw usiłowanych $i$ dokonanych współczesnej młodzieży (doniesienia z badań). W: W. Kubik, B. Urban (red.), Uwarunkowania $i$ wzory marginalizacji społecznej współczesnej młodzieży. Kraków, Wydawnictwo WAM, 315-328.

Meyer A., Rose D.H., Gordon D., 2016, Universal Design for Learning. Theory and practice. Wakefield, CAST Professional Publishing.

Nowak A., 2012, Zagrożenie wykluczeniem społecznym kobiet niepełnosprawnych. Katowice, Wydawnictwo Uniwersytetu Śląskiego.

Nowak-Adamczyk D., 2014, Studenci z zaburzeniami psychicznymi $w$ przestrzeni akademickiej - system wsparcia edukacyjnego na Uniwersytecie Jagiellońskim w Krakowie. „Niepełnosprawność - zagadnienia, problemy, rozwiązania”, nr 4, 73-94.

Palus K., 2007, Realizacja zadań rozwojowych jako czynnik i kryterium rozwoju indywidualnego. W: B.M. Kaja, A. Molesztak (red.), Wspomaganie rozwoju. Psychostymulacja i psychokorekcja. Bydgoszcz, Uniwersytet Kazimierza Wielkiego w Bydgoszczy, 40-51.

Papież J., 2005, Samotność młodzieży jako syndrom wykluczenia społecznego. W: T. Sołtysik (red.), Zagrożenia $w$ wychowaniu i socjalizacji młodzieży oraz możliwości ich przezwyciężania. Bydgoszcz, Wydawnictwo Akademii Bydgoskiej im. Kazimierza Wielkiego, 87-100.

Podgórska-Jachnik D., Pietras T., 2014, Praca socjalna z osobami z zaburzeniami psychicznymi i ich rodzinami. Warszawa, Centrum Rozwoju Zasobów Ludzkich. Przybylak A., Rojek M., 2011, Studenckie koła naukowe, czyli na liderskim stażu. W: S.M. Kwiatkowski, J.M. Michalak, I. Nowosad (red.), Przywództwo edukacyjne w szkole i jej otoczeniu. Warszawa, Fundacja Rozwoju Edukacji, 200-212.

Rzecznik Praw Obywatelskich, 2015, Dostępność edukacji akademickiej dla osób $z$ niepełnosprawnościami. Analiza i zalecenia. Warszawa, Biuro Rzecznika Praw Obywatelskich.

Rongińska T., Gaida W.A., 2012, Strategie radzenia sobie z obciążeniem psychicznym w pracy zawodowej. Zielona Góra, Oficyna Wydawnicza UZ.

Rzymełka-Frąckiewicz A., 2011, Rola grupy rówieśniczej w procesie socjalizacji młodego pokolenia w warunkach zmiany społecznej. W: S.M. Kwiatkowski, J.M. Michalak, I. Nowosad (red.), Przywództwo edukacyjne w szkole i jej otoczeniu. Warszawa, Difin, 300-314.

Sęk H., 2004, Wypalenie zawodowe u nauczycieli. Uwarunkowania i możliwości zapobiegania. W: H. Sęk (red.), Wypalenie zawodowe. Przyczyny i zapobieganie. Warszawa, Wydawnictwo Naukowe PWN, 149-167.

Skalska K., 2018, Włączenie studentów doświadczających kryzysów zdrowia psychicznego do pełnego uczestnictwa w społeczności akademickiej na przykładzie 
projektu „Przyjazny Uniwersytet” realizowanego na Uniwersytecie Marii CurieSkłodowskiej w Lublinie. DOI: 10.4467/25439928PS.18.002.8508

Ślusarczyk C., 2013, Projektowanie uniwersalne jako sposób na tworzenie warunków do edukacji właczającej w szkołach wyższych. „E-mentor”, nr 5, 65-68.

Szymańska J., 2016, Zapobieganie samobójstwom dzieci i młodzieży. Poradnik dla pracowników szkół i placówek oświatowych oraz rodziców. Warszawa, Ośrodek Rozwoju Edukacji.

Zalewska A., 2016, Kultura relacji nauczyciel akademicki - student. W: B. Bokus, E. Kosowska (red.), Nauczyciel akademicki - etos i warsztat. Piaseczno, Studio Lexem, 19-29.

Wasilewska-Ostrowska K., 2015, Profilaktyka zachowań suicydalnych wśród młodzieży. „Dziecko krzywdzone. Teoria, badania, praktyka”, vol. 14, nr 3, $153-164$.

Wawak T., 2012, Jakość zarządzania w szkołach wyższych. Kraków, Wydawnictwo Uniwersytetu Jagiellońskiego.

\title{
THE GOOD LIFE PROJECT IMPLEMENTED AT THE MARIE CURIE-SKŁODOWSKA UNIVERSITY IN LUBLIN AS AN EXAMPPLE OF UNIVERSAL DESIGN
}

\begin{abstract}
This article presents the experience of the Marie Curie-Skłodowska University in the field of universal design at the higher education level. Universal design in education assumes creating programs, materials, but also an environment accessible to students with different needs arising from the style of learning, age, health status, language skills, life and cultural experiences. The idea of universal design has been used in the preventive project Good Life. The primary goal of the project was preventing suicidal behavior among academic youth. The activities undertaken in accordance with the idea of universal design were addressed to the entire academic community and were based on a four-link operation model: student, peer group, academic teachers, disabled persons' support team.
\end{abstract}

Keywords: universal design, student, suicide 